\title{
Pencatatan Transaksi pada Usaha Keluarga Skala Kecil dengan Pendekatan Socioemotional Wealth
}

\author{
Ananda Eka Wardhani* \\ Fakultas Ekonomika dan Bisnis Universitas Kristen Satya Wacana Salatiga
}

\section{A R T I C L E I N F O}

Article history:

Received 15 February 2020

Received in revised form

30 March 2020

Accepted 20 April 2020

Available online 28 May 2020

Kata Kunci:

Usaha Keluarga Skala Kecil , Socioemotional Wealth,

Pencatatan Transaksi.

Keywords:

Small Scale Family Business,

Socioemotional Wealth

Transaction Record.

\begin{abstract}
A B S T R A K
Anggota keluarga sebagai pemilik atau pemangku kepentingan mayoritas dalam usaha keluarga sering kali ikut campur pada usaha dengan mengabaikan prinsip manajemen usaha. Penelitian ini bertujuan untuk untuk mengeksplorasi pencatatan Usaha Kecil Menengah (UKM) melalui pendekatan Socioemotional Wealth (SEW). Transaksi dan peran anggota keluarga di usaha keluarga Toko Ganda dalam lingkup. Data primer diperoleh melalui hasil wawancara dengan informan kunci yaitu pemilik usaha. Hasil penelitian menunjukkan bahwa keluarga masih memiliki pengaruh besar dalam menjalankan usaha terlebih dalam pencatatan transaksi sebagai dampak dari kesejahteraan keluarga yang menjadi dasar pertimbangan dalam pengambilan keputusan.
\end{abstract}

Family business as the owner or majority stakeholder in the family business often intervene in the business by ignoring business management principles. The research aim to explore the recording of transactions and the role of family members in the double-store family business in scope Small Medium Enterprises (SMES) through Socioemotional Wealth (SEW) approach. Primary data obtained through interviews with the key informan that is the business owner. The results showed that the family still had a major influence in running the business in the recording of transactions as a result of

\footnotetext{
* Corresponding author.

E-mail addresses: anandaekawardhani27@gmail.com (Ananda Eka Wardhani)
} 


\section{Pendahuluan}

Perekonomian Indonesia didominasi oleh usaha kecil yang jumlahnya lebih dari 26 juta usaha atau 98,68 persen dari total unit usaha non pertanian di Indonesia (Badan Pusat Statistik, 2018). Hal ini membuktikan bahwa usaha skala kecil mempunyai peran penting dalam perekonomian di Indonesia. Pengembangan usaha keluarga skala kecil menjadi wujud nyata dari kegiatan ekonomi rakyat dengan mengandalkan kekuatan sendiri, terdisentralisasi, beragam, dan kelompok usaha yang mampu menjadi penunjang saat perekonomian dilanda krisis (Sulistyo, 2010). Niode (2009) menunjukkan bahwa usaha keluarga skala kecil sudah terbukti dapat memberikan kontribusi besar, terlebih dalam peningkatan kesejahteraan perekonomian. Usaha keluarga skala kecil atau sering disingkat menjadi (UKM) menjadi tempat yang baik dalam menciptakan lapangan pekerjaan produktif yang memiliki sifat padat karya dan tidak memerlukan persyaratan khusus seperti tingkat pendidikan (Sulistyo, 2010).

Pencatatan transaksi keuangan pada usaha mulai dilakukan sejalan dengan praktik akuntansi yang berubah seiring dengan perkembangan jaman. Hal ini telah diungkapkan oleh Barney, Nelson, dan Winter (1987) yang mengatakan bahwa lambat laun usaha berevolusi dan hal tersebut berpengaruh pada praktik akuntansi yang juga berubah secara bertahap.

Pencatatan transaksi mulai dianggap penting dalam perkembangan usaha. Akan tetapi kebanyakan dari usaha keluarga skala kecil tidak mencatat transaksi dalam usaha. Hal ini dibenarkan oleh Sharma, (2004), yang mengemukakan bahwa banyak transaksi yang terjadi dalam usaha keluarga kecil yang tidak dicatat karena tidak adanya ketergantungan antara pembeli dan penjual begitu transaksi selesai. Selama transaksi masih mudah maka tidak perlu adanya pencatatan (Williamson, 1985). Selain itu, beberapa usaha keluarga telah menerapkan pencatatan trsansaksi, namun mayoritas praktik yang diterapkan didasarkan pada budaya dan hubungan sosial dalam usaha. Sebagian besar keputusan manajerial dibuat dengan sedikit perhatian untuk data akuntansi formal dan lebih banyak perhatian untuk kesejahteraan keluarga (Tsamenyi, Noormansyah, \& Uddin, 2008).

Kemudian Cherchem (2017) berpendapat bahwa perubahan praktik akuntansi saat ini menjadi bahasa untuk perkembangan pengetahuan: pemimpin generasi ketiga menggunakan informasi untuk menegakkannya kepemimpinan dan untuk menjelaskan strategi yang diperlukan untuk mempertahankan persaingan usaha yang menguntungkan di pasar maka diperlukan adanya pencatatan dalam setiap transaksi usaha. Bagaimanapun pemilik memegang kekuasaan lebih untuk menentukan penerapan pencatatan transaksi, dimana pencatatan dibuat berdasarkan kebutuhan yang tergantung pada situasi mereka sendiri (Huerta, Petrides, \& O’Shaughnessy, 2017).

Pembahasan mengenai UKM tidak dapat terlepas kaitannya dengan usaha keluarga. Dari peninjauan yang dilakukan oleh PricewaterhouseCooper (PwC) pada tahun 2014, jumlah dari seluruh unit usaha yang berada di Indonesia 95 persen di isi oleh usaha keluarga (PwC et al., 2016). Hal ini menunjukkan bahwa UKM di Indonesia didominasi atau hampir seluruhnya merupakan usaha keluarga skala kecil.

Usaha keluarga skala kecil memerlukan pengelolaan keuangan yang baik. Irfani dan Dahria (2013) mengemukakan bahwa akuntansi sangat diperlukan oleh pihak-pihak yang memiliki kepentingan dalam memanfaatkan informasi akuntansi sebagai dasar dalam penyusunan perencanaan yang efektif serta untuk pengambilan keputusan usaha.

Usaha keluarga merupakan usaha yang diturunkan kepada anggota keluarga, yang mana didalamnya terdapat hubungan antara usaha dengan pemilik yang merupakan pendiri dan bertindak sebagai Chief Executive Officer (CEO), anggota keluarga sebagai pengelola, dan setidaknya satu lainnya karyawan (Burkart, Panunzi, \& Shleifer, 2003). Sedangkan yang dimaksud dengan usaha kecil merupakan bentuk usaha yang memiliki penghasilan dibawah 1 miliar dan hanya memiliki jumlah karyawan 5 sampai dengan 10 (BPS, 2016). Sehingga usaha keluarga skala kecil adalah bentuk usaha yang dimiliki dan dikelola oleh keluarga sebagai pemegang kendali dan memiliki omset dan jumlah karyawan yang sedikit.

Peran seorang anggota keluarga sebagai bawahan sangat penting, karena ini menunjukkan hubungan hirarkis dimana pemilik memiliki kekuatan yang lebih besar daripada karyawan dan dengan mempertimbangkan keturunan garis keluarga (anak-anak dan cucu) dan keluarga non-inti (pasangan, sepupu, bibi, paman, atau mertua) (Huerta, Petrides \& O'Shaughnessy, 2017). Penelitian ini tertuju pada usaha keluarga yang antar generasi, yaitu dengan lebih dari satu generasi dari keluarga yang saat ini memiliki dan mengelola usaha. Sejumlah penelitian menganggap bahwa usaha keluarga merupakan usaha yang memiliki potensi jangka panjang dan berorientasi pada perekonomian negara (Brigham et al., 2014).

Definisi usaha keluarga lebih sering berdasar pada komponen yang mempengaruhi dan bukan pada hal-hal yang termasuk dasar pembentuknya. Seharusnya definisi usaha keluarga dibentuk berdasarkan tujuan dari kondisi sesungguhnya dan bagaimana untuk mencapai tujuan bersama yaitu melampaui beberapa generasi (Wahjono, 2009). Oleh karena itu usaha keluarga diartikan sebagai unit usaha yang 
dijalankan oleh keluarga atau kelompok keluarga yang memeilik visi yang sama dan bermaksud untuk mencapai visi tersebut.

Praktik akuntansi dalam usaha keluarga skala kecil menengah masih kurang dipahami, dengan hanya sejumlah kecil studi yang membahas masalah ini (e.g. Mitchell \& Reid, 2000). Akan tetapi, Salvato dan Moores (2010) menyatakan bahwa literatur tentang akuntansi dalam usaha keluarga telah berkembang secara sistematis dalam tiga dekade. Literatur tersebut menunjukkan bahwa usaha keluarga belum mempertimbangkan akuntansi karena pemilik belum menyadari manfaat dari hasil pencatatan transaksi-transaksi secara akuntansi dalam usaha. Pemilik usaha keluarga skala kecil beranggapan bahwa informasi akuntansi akan diterapkan ketika benar-benar dibutuhkan dan berpikir bahwa selama dia tahu kemana usaha harus bergerak, pengetahuan ini dianggap cukup (Hiebl, 2013). Hal itu membuat pemilik usaha keluarga memilih untuk tidak menerapkan praktik akuntansi dalam usaha.

Pengelolaan keuangan dalam usaha keluarga skala kecil sering kali menjadi salah satu penghambat usaha dalam berkelanjutan. Usaha keluarga cenderung terlibat dalam logika keuangan yang tidak hanya pada dimotivasi oleh alasan ekonomi rasional tetapi juga pada pribadi untuk pertumbuhan, risiko, kepentingan keluarga, dan kontrol kepemilikan (Gallo, Tàpies, \& Cappuyns, 2004). Pemilik usaha keluarga tidak mau melakukan pencatatan karena khawatir hal itu akan mengganggu keharmonisan dalam keluarga dan kesejahteraan keluarga menjadi tolok ukur utama dalam menjalankan usaha. Huerta, Petrides, dan O'Shaughnessy (2017) menemukan bahwa penerapan pencatatan transaksi secara akuntansi yang disarankan oleh karyawan anggota keluarga akan dievaluasi oleh pemilik sebagai pengambil keputusan apakah akan menerapkan pencatatan secara akuntansi atau tidak, sedangkan saran yang diberikan oleh karyawan non-keluarga dan eksternal diabaikan oleh pemiliknya.

Pernyataan terkait dengan penelitian di atas berhubungan dengan Socioemotional Wealth (SEW). SEW merupakan suatu istilah yang mengacu pada tujuan-tujuan non-finansial usaha untuk memenuhi kebutuhan afektif keluarga, seperti kemampuan untuk menjalankan pengaruh keluarga dalam keputusan, mempertahankan identitas keluarga, dan kelangsungan dinasti keluarga (Gómez-Mejía et al., 2007).

Hasil penelitian Kalm dan Gomez-Mejia (2016), menunjukkan bahwa SEW melekat pada usaha keluarga di mana ikatan emosional antar anggota keluarga menjadi tolok ukur utama dalam pengambilan keputusan usaha, baik itu finansial maupun non finansial pada pembuatan keputusan manajerial. Usaha keluarga mempertimbangkan pelestarian SEW dengan mengesampingkan faktor keuangan. Barry (1989) mengemukakan bahwa pengambilan segala keputusan usaha yang penting pada usaha keluarga dikendalikan oleh anggota keluarga tunggal khususnya sebagai penentu kebijakan. Isu tentang SEW yang melekat pada usaha keluarga skala kecil menarik untuk diteliti dengan keluarga sebagai pengaruh kebijakan.

Penelitian ini melibatkan usaha keluarga skala kecil yang sudah melakukan pencatatan transaksi. Toko Ganda merupakan salah satu UKM yang sudah melakukan pencatatan transaksi, akan tetapi memilih untuk tidak melakukan pencatatan secara lebih sistematis sehingga usaha ini dipilih menjadi obyek penelitian untuk mengetahui pencatatan akuntansi yang ada dalam usaha keluarga dari generasi ke generasi. Toko Ganda merupakan salah satu bentuk usaha keluarga skala kecil skala yang ada di Ungaran, Jawa tengah. Objek penelitian ini didasarkan pada unsur dalam usaha, yaitu usaha yang dikelola oleh keluarga dan sudah beralih generasi kepemilikan.

Penelitian ini mengacu pada penelitian Perren dan Grant (2000) untuk menjelaskan praktik akuntansi yang ada dalam usaha keluarga skala kecil terkait dengan SEW, khususnya dalam pencatatan transaksi. Secara lebih rinci, Perren dan Grant (2000) menemukan bahwa karyawan non keluarga dan ahli eksternal memiliki pengaruh yang rendah pada praktik akuntansi meskipun diperkerjakan oleh pemilik. Hal ini berarti bahwa ikatan anggota keluarga masih menjadi kekuatan terbesar dalam pengambilan keputusan keuangan sebagaimana mengacu pada dimensi SEW. Pertanyaan dalam penelitian ini yaitu: Bagaimana pencatatan transaksi yang dilakukan di Toko Ganda? Bagaimana keluarga berpengaruh dalam pengambilan keputusan keuangan Toko Ganda? Sehingga penelitian ini bertujuan untuk mengeksplorasi pencatatan transaksi dan peran anggota keluarga pada usaha keluarga melalui pendekatan SEW. Penelitian ini diharapkan memberikan gambaran mengenai pencatatan transaksi pada usaha keluarga skala kecil di Ungaran dan dapat menjadi masukan untuk pengembangan usaha keluarga skala kecil yang lain dengan adannya praktik akuntansi. Selain itu, penelitian diharapkan dapat menjadi masukan bagi peneliti lain yang akan melakukan penelitian sejenis.

Socioemotional Wealth (SEW) mengacu pada aspek non finansial dari usaha untuk memenuhi kebutuhan non ekonomi keluarga melalui usaha (Stockmans, Lybaert \& Voordeckers, 2010). Model SEW menunjukkan bahwa usaha keluarga cenderung menempatkan prioritas untuk mempertahankan kendali keluarga, menerima peningkatan risiko kinerja anggota keluarga yang buruk, dan mencegah usaha dari kegagalan di atas kinerja keuangan yang mendorong usaha keluarga bertindak lebih konservatif (Gomezmejia, 2010). Sebagai contoh, Berrone et al., (2010) yang menyatakan bahwa nilai SEW untuk keluarga 
lebih intrinsik, tujuannya adalah untuk melestarikan usaha yang sudah turun-temurun, dan itu berlabuh di tingkat psikologis yang mendalam di antara anggota keluarga yang identitasnya tidak dapat dipisahkan dengan usaha.

Tertib administrasi (formalisasi) membantu usaha dalam mengingat melalui pencatatan, meningkatkan keterampilan untuk diterapkan kegiatan masa depan dengan adanya review dari hasil pencatatan formal, dan meningkatkan komitmen anggota dengan mendorong mereka untuk menetapkan tujuan yang jelas yang sesuai dengan tujuan dari usaha. Akan tetapi, usaha keluarga skala kecil memilih untuk mengandalkan sistim informasi yang tidak formal karena dianggap menghambat kinerja usaha dengan mengganggu keharmonisan ikatan keluarga dalam perusahaan (Kirca et al., 2005) atau yang dikenal dengan sebutan SEW.

SEW sering kali menjadi hal yang tidak dapat dipisahkan dalam menjalankan praktik akuntansi usaha keluarga. Dalam praktik akuntansi, SEW model berkaitan dengan pengambilan keputusan penerapan praktik akuntansi. Keputusan pelaporan keuangan di usaha keluarga didasarkan pendekatan dalam SEW yang artinya bahwa usaha keluarga mempertimbangkan aspek non finansial usaha (SEW) yaitu untuk memenuhi kebutuhan afektif keluarga (Carrera, 2017).

Huerta, Petrides, dan O'Shaughnessy (2017) mengatakan bahwa dalam SEW, hubungan anggota keluarga memungkinkan mereka memberikan pengaruh pada pencatatan transaksi usaha. Pemilik percaya bahwa anggota keluarga menginginkan yang terbaik untuk keluarga dan usaha yang dimiliki oleh keluarga sehingga pencatatan dilakukan dengan tujuan khusus yaitu untuk melestarikan dan mengembangkan dimensi dalam SEW. Kemudian Koropp et al., (2014) menemukan bahwa keputusan finansial dalam usaha keluarga sebagian besar dipengaruhi oleh norma-norma hubungan kekeluargaan sebagai pengaruh tertinggi dalam pembuat keputusan. Selain dalam pengenalan, anggota keluarga juga berperan penting untuk perkembangan praktik akuntansi yang dilakukan dalam usaha utamanya dalam pencatatan transaksi.

Pilihan pencatatan akuntansi yang terkait dengan pelestarian SEW menjadi kompleks. Kepemilikan keluarga dianggap mengurangi distorsi dalam pelaporan yang dapat dilakukan manajemen agar terlihat bagus, seperti agresivitas pajak dan manipulasi laba. Usaha keluarga tampaknya membuat pilihan di bidang ini untuk melestarikan SEW dengan menghindari negatif publisitas, mempertahankan reputasi usaha yang baik, dan memproyeksikan citra keluarga yang positif (Berrone, Cruz, \& Gomez-Mejia, 2012).

Keputusan semacam itu dapat secara langsung mempengaruhi kinerja keuangan usaha karena tujuan yang dicapai harus bermanfaat dalam pelestarian SEW antar anggota keluarga, daripada mengejar kinerja keuangan semata. Kebutuhan untuk melestarikan SEW sangat erat dalam usaha keluarga skala kecil (Gomez-Mejia et al., 2011). Jika mereka dianggap membuat keputusan yang berkaitan dengan kebutuhan mendesak anggota keluarga yang bertentangan dengan nilai jangka panjang untuk usaha keluarga, mereka akan tetap melakukannya meskipun dianggap tidak adil untuk kesehatan finansial usaha (Sharma, 2004).

\section{Metode}

Obyek dari penelitian ini yaitu Toko Ganda. Toko Ganda merupakan salah satu usaha keluarga skala kecil yang ada di Ungaran, Kabupaten Semarang, Jawa Tengah. Toko ini merupakan distributor sembako (sembilan bahan pokok) di Pasar Bandarjo Ungaran. Usaha keluarga yang dipilih adalah usaha keluarga yang sudah diturunkan atau berganti generasi dan masih bertahan sampai saat ini. Kepemilikan Toko Ganda sudah berada pada generasi ketiga.

Langkah awal penelitian ini menyusun daftar pertanyaan yang berkaitan dengan data yang dibutuhkan,yaitu latar belakang Toko Ganda, sistem pencatatan transaksi pada Toko Ganda, perubahan praktik pencatatan transaksi pada Toko Ganda, dan pengaruh anggota keluarga pada pencatatan transaksi Toko Ganda. Kemudian penulis menentukan informan kunci yang dijadikan sebagai narasumber yaitu orang-orang yang terlibat dalam usaha (pemilik dan pengelola usaha). Selanjutnya yang ketiga adalah melakukan wawancara dengan informan.

Penelitian ini menggunakan data primer. Data primer yang digunakan dalam pen elitian ini berupa: profil pemilik, profil pengelola, profil usaha, pencatatan transaksi yang dijalankan dalam setiap generasi, perubahan dalam pencatatan transaksi, keterlibatan anggota keluarga dalam pencatatan transaksi usaha, dan proses pembuatan keputusan dalam usaha. Data tersebut didapatkan dari informan kunci yaitu pemilik usaha sebagai narasumber yang memahami bagaimana proses usaha dijalankan dan pengelolaan usaha dilakukan.

Berdasarkan sumber data yang dipakai dalam penelitian ini, peneliti mengumpulkan data melalui wawancara kepada informan kunci. Wawancara dilakukan untuk mendapatkan informasi yang lebih akurat dan terperinci tentang awal mula pencatatan dilakukan, bagaimana pencatatan transaksi 
berkembang dalam usaha keluarga, dan bagaimana anggota keluarga berpengaruh terhadap pencatatan. Wawancara dilakukan dengan mengajukan beberapa pertanyaan berkaitan dengan data yang dibutuhkan dalam penelitian. Kemudian observasi dilakukan dengan melihat praktek operasi usaha yang terjadi di Toko Ganda. Dokumentasi diambil untuk menjadi bukti pencatatan transasksi.

Setelah data-data dari hasil wawancara, observasi, dan dokumentasi terkumpul yang dilakukan selanjutnya adalah memilih data yang digunakan atau diperlukan untuk kemudian diolah dan dianalisis. Untuk menjawab persoalan penelitian pertama berdasarkan data dari profil usaha, pencatatan transaksi dalam usaha, dan perubahan dalam pencatatan yang dilakukan. Data akan diidentifikasi apakah sudah melakukan pencatatan transaksi, bagaimana pencatatan transaksi yang dilakukan dalam usaha keluarga, kapan pencatatan dilakukan, apa bentuk dari hasil pencatatan yang dilakukan, dan bagaimana output dari pencatatan tersebut digunakan (digunakan untuk apa). Persoalan penelitian kedua dijawab dengan data profil usaha, profil pemilik dan pengelola, perubahan dalam pencatatan, pengaruh peran keluarga pada usaha, dan proses pembuatan keputusan dalam usaha keluarga dengan mengidentifikasi siapa yang menginisiasi pencatatan dalam setiap praktik akuntansi, siapa yang memberikan pengarahan dalam pencatatan, siapa yang melakukan pencatatan, dan bagaimana perkembangan pencatatan dalam setiap perubahan generasi. Output dari persoalan penelitian akan dijelaskan dengan menggunakan dimensidimensi dalam SEW. Setelah semua data diolah dan dianalisis, kalimat disusun dan dibuat dengan sistematis dan jelas agar hasil penelitian mudah dipahami.

\section{Hasil dan pembahasan}

\section{A. Profil Toko Ganda}

Toko Ganda merupakan usaha keluarga yang bergerak di bidang distributor sembako di Pasar Ungaran. Usaha ini sudah didirikan sejak 48 tahun yang lalu. Usaha keluarga ini didirikan oleh Ibu Kartopawiro pada tahun 1971, kemudian berkembang dan diteruskan oleh Ibu Mujiyem anak dari Ibu Kartopawiro tahun 1976, kemudian setelah Ibu Mujiyem meninggal, usaha ini diteruskan oleh Ibu Ganda anak dari Ibu Mujiyem pada tahun 1990 sampai sekarang.

\section{B. Proses Re-Generasi Toko Ganda}

Toko Ganda mengalami perkembangan yang cukup pesat dari generasi pertama sampai ke generasi tiga sebelum akhirnya Toko Ganda menjadi toko distributor sembako usaha keluarga ini mengalami perubahan-perubahan. Awalnya Ibu Kartopawiro (generasi pertama) hanya berjualan kelapa saja dengan mengambil dari pemasok, kemudian dijual langsung dan belum bernama Toko Ganda, toko ini tidak diberi nama.

Kemudian setelah Ibu Kartopawiro meninggal, usaha ini dilanjutkan oleh Ibu Mujiyem (generasi kedua) yaitu anak dari Ibu Kartopawiro. Pada masa kepemilikan Ibu Kartopawiro, toko ini kemudian diberi nama Toko Ganda yaitu dengan nama anak dari Ibu Kartopawiro. Lambat laun usaha ini berkembang kemudian beralih menjadi Toko Sembako (Sembilan Bahan Pokok) yang dijual langsung kepada konsumen dan usaha ini masih terbilang kecil.

Tahun 1990, setelah Ibu Mujiyem meninggal, usaha ini diteruskan oleh Ibu Ganda (generasi ketiga) sebagai anak perempuan kedua dari Ibu Mujiyem. Usaha Sembako yang diturunkan kepada Ibu Ganda menjadi semakin besar dan berkembang. Toko Ganda berubah dari penjualan langsung menjadi distributor Sembako di Pasar Ungaran. Hal ini juga merupakan pengaruh dari perkembangan jaman yang semakin maju.

Usaha keluarga skala kecil milik Ibu Ganda ini diteruskan turun-temurun tak lepas dari anggota keluarga dari pendiri binis dan pemilik usaha itu sendiri. Masing-masing generasi dalam usaha ini memiliki alasan yang sama dalam menjalankan usaha, yaitu lebih kepada pemenuhan kebutuhan keluarga. Penerus dari peralihan generasi dalam usaha keluarga ini sudah masuk kedalam bagian dari usaha sebelum Toko Ganda diturunkan kepada generasi selanjutnya agar penerus dari usaha memahami situasi dan sistem kerja dari usaha keluarga sebelum dialihkan kepemilikan sehingga usaha keluarga dapat berlanjut dan bertahan.

Dalam menjalankan usaha ini Ibu Ganda dibantu oleh dua anaknya yang ikut membantu dan terkadang menantu Ibu Ganda juga ikut membantu. Selain itu, ada tiga karyawan yang saat ini bekerja di usaha Toko Ganda. Salah satu dari anak atau menantu Ibu Ganda inilah yang nantinya akan menjadi penerus usaha keluarga milik Ibu Ganda meskipun Ibu Ganda sendiri belum tahu siapa nantinya yang akan menggantikan sebagai pemilik usaha Grosir Toko Ganda. 


\section{Pencatatan Transaksi Pada Toko Ganda}

Pencatatan transaksi penting untuk dilakukan dalam usaha. Pencatatan transaksi yang digunakan oleh setiap pemilik usaha dari generasi ke generasi pasti berbeda. Sama halnya dengan pencatatan transaksi dari usaha keluarga di Toko Ganda yang berbeda cara pencatatannya dari generasi pertama ke generasi penerus. Perkembangan usaha merupakan salah satu faktor pencatatan transaksi dilakukan. Hal ini didapatkan dari pernyataan Ibu Ganda:

"Kalau nenek tidak, cuma sistem mengingat seperti orang jualan dipasar, kalau sekarang kan sudah semakin berkembang ya, sudah pencatatan, kalau dulu tidak pernah dicatat. "

Pencatatan transaksi dalam usaha keluarga Toko Ganda ini baru mulai dilakukan pada generasi ketiga, yaitu Ibu Ganda. Pencatatan transaksi baru mulai dilakukan ketika dianggap perlu. Pemilik mulai menyadari bahwa pencatatan transaksi memiliki manfaat yang baik dalam usaha, sehingga perlu adanya pencatatan transaksi. Dalam pernyataan di atas dapat dilihat bahwa pencatatan transaksi ini mengalami perkembangan sejalan dengan perpindahan generasi kepemilikan dalam Toko Ganda yaitu yang tadinya tidak mencatat sama sekali sampai kemudian pencatatan transaksi dilakukan pada generasi ketiga dengan Ibu Ganda sebagai pemilik.

"Kan dengan sendirinya, misal "oh itu tadi utang sepuluh juta" nanti kalau tidak dicatat dia tidak ingat, "saya hutangnya cuma satu juta" gitu kan. Kalau dicatat kan nanti ada "oh tanggal ini, ini sudah dua tahun bu" gitu. Namanya orang kan lupa, tiga hari saja lupa. Nanti padahal belum bayar tapi bilangnya sudah bayar, kan kadang dicatat ada buktinya. kalo ada utang tetap harus ditulis, kalau tidak ditulis nanti lupa."

Dari pernyataan Ibu Ganda, dapat dilihat bahwa alasan untuk akhirnya pencatatan transaksi dilakukan yaitu karena pemilik menyadari bahwa pencatatan transaksi dapat membantu untuk mengetahui transaksi yang ada dalam usaha keluarga ini atau dengan kata lain pencatatan transaksi membantu Ibu Ganda dalam mengingat transaksi-transaksi yang dilakukan pada Toko Ganda. Akan tetapi, pencatatan transaksi dalam usaha Toko Ibu Ganda ini masih terbilang sederhana, belum terlalu kompleks atau mendetail pada setiap transaksi usaha, dan pencatatan beum dilakukan secara tersruktur. Hanya beberapa transaksi saja yang dicatat, yaitu:

" Pengeluaran, bayar giro, sama itu kadang kan ada yang bayar tunai-tunai gitu kan. Bayar giro itu ada bukunya, seperti tanggal ini bulan ini gitu bayar giro, jadi kan tahu, oh bulan ini pengeluaran giro segini-segini."

Pencatatan transaksi dalam usaha keluarga ini hanya transaksi-transaksi yang dianggap perlu untuk dicatat sedangkan yang lainnya dianggap tidak memerlukan pencatatan sehingga transaksi yang dicatat dalam usaha keluarga skala kecil ini hanya transaksi penjualan kredit dan tunai, kemudian transaksi pengeluaran tunai.

"Mungkin karena tempat saya jualannya tidak seperti mini market ya, jadi ya masih manual. Jadi kan yang menangani saya sendiri, jadi kan oh tahu gitu kan. Mungkin kalau yang pegang orang lain mungkin kan ada pembukuan, ada barang masuk barang keluar gitu ya. Buku utang masuk (piutang dagang) pelanggan yang minta saya catat sendiri. Katakanlah mbak A utang saya lima ratus, besok membayar (mbak A utang saya lima ratus, besok bayar) begitu saja."

Transaksi sederhana yang terjadi dalam Toko Ganda menjadi salah satu faktor penyebab pencatatan lain belum dilakukan. Ibu Ganda menganggap bahwa pencatatan secara kompleks atau formal belum dibutuhkan dalam usaha keluarga Toko Ganda pada saat ini meskipun sebenarnya Ibu Ganda menyadari bahwa diperlukannya adanya pencatatan transaksi yang lebih mendetail pada usaha keluarga milik Ibu Ganda. Akan tetapi, menurut Ibu Ganda pencatatan transaksi secara kompleks hanya akan menyita waktu dan pikiran sehingga tidak dilakukan meskipun sudah ada banyak orang yang menyarankan baik itu dari keluarga ataupun dari non keluarga (teman). Hal ini disampaikan oleh Ibu Ganda dalam wawancara berikut:

"Ya perlu, harusnya perlu. Tapi namanya saya sudah tua kan pikirannya tidak seperti remaja, jadi kadang mengotak-atik begitu pusing, kadang kelamaan, kadang mata sudah tidak jelas jadi kan saat baru mau mengoperasikan komputer/mesin kasir keburu ada yang beli harus segera dilayani. Itu ada (mesin barcode), seharusnya itu memang pedagang harus punya itu, jadi menulis tidak keliru seharusnya itu memang pedagang tu harus punya itu, jadi nulis tidak keliru. Upamannya nulis satu juta nanti nulisnya jadi seratus ribu, itu kadang sering juga sih namanya sudah tua. Kadang nota berat, habisnya lima juta ternyata seharusnya lima juta lima ratus karena yang lima ratus ribu itu ditulis lima puluh ribu. Ya perlu,harusnya perlu, harusnya ada komputer."

Perlunya adanya pencatatan transaksi secara kompleks ini sebenarnya disadari oleh pemilik dengan permasalahan-permasalahan yang timbul sebagai akibat dari tidak dilakukannya pencatatan transaksi-transaksi lain. Akan tetapi keterbatasan kemampuan yang dimiliki oleh pemilik menjadi penyebab hal tersebut tidak diakukan. Kemudian pada usaha keluarga skala kecil milik Ibu Ganda, tidak 
dilakukan adanya pemisahan dalam aset atau keuangan keluarga dengan usaha juga memberi dampak lainnya yaitu tidak adanya pencatatan atau penghitungan laba usaha.

"Saya tidak pernah menghitung, yang penting jalani saja, masih dicampur-campur, ngitung itu pusing, karena apa, pengeluaran sama laba itu terkadang lebih banyak yang dikeluarkan. Contohnya gini sekarang sepi gitu ya, padahal pengeluaran sekarang satu juta sehari, katakanlah labanya dua ratus, mengeluarkan satu juta contohnya, untuk kondangan dua orang, katakanlah seratus kan dua orang jadi dua ratus, trus nanti masih servis motor, dan lain lain gitu kan. Jadi hari ini mengeluarkan satu juta, padahal laba kan cuma dua ratus, kan jadi kalau ngitung kan pusing. Tidak tahu lah lillahita'ala, nanti suatu saat besok ramai, labanya satu juta, tapi tidak ada pengeluaran, gitu kan jadinya timbal balik, jadi tidak usah dipikir, pusing."

Pencatatan transaksi pengeluaran usaha dan pribadi tidak dilakukan sehingga memberi dampak pada tidak diketahuinya laba pasti dalam Toko Ganda dan tidak adanya kontrol pengeluaran yang seharusnya bisa dilakukan dengan adanya pencatatan. Dalam kasus ini, Ibu Ganda menjadi pesimis dengan melihat pengeluaran sehari-hari yang terkadang lebih besar daripada laba harian yang didapatkan sehingga memutuskan untuk lebih baik tidak usah dicatat. Pencatatan secara kompleks dianggap hanya akan menambah rumit pekerjaan. Pencatatan pada Toko Ganda dilakukan hanya pada transaksi-transaksi tertentu yang dianggap diperlukan dan bertujuan sebagai catatan pengingat.

\section{Aspek SEW dalam Pencatatan Transaksi Toko Ganda}

Pencatatan dalam usaha keluarga milik Ibu Ganda ini baru dimulai ketika sudah diturunkan kepada Ibu Ganda. Sebelumnya, Ibu Ganda sudah pernah menyarankan sejak usaha ini masih dipegang oleh Ibu Mujiyem. Ibu Ganda menyarankan untuk mencatat piutang-piutang yang masuk dari pelanggan. Akan tetapi ditolak oleh Ibu Mujiyem yang merasa tidak perlu untuk melakukannya saja sudah bisa.

"Dulu memang saya sudah sempat menyarankan kepada Ibu saat saya membantu berjualan, tapi Ibu saya nggak mau soalnya dianggapnya terlalu ribet dan ingatannya masih bisa, jadi cuma sistem ingatan saja"

Aspek SEW dalam usaha keluarga skala kecil menjadikan pentingnya peranan keluarga dalam perubahan yang terjadi. Anggota keluarga memberikan pengaruh besar terhadap keputusan-keputusan yang akan diambil. Dalam kasus ini, anggota keluarga berpengaruh dalam dilakukan atau tidaknya pencatatan transaksi dalam usaha.

Pencatatan transaksi ini dimulai dengan inisiatif sendiri dari Ibu Ganda karena dianggap perlu dilakukan untuk mempermudah kegiatan operasional usaha. Awal mulanya Ibu Ganda hanya mencatat piutang dagang, kemudian ditambah dengan pencatatan pengeluaran seperti membayar utang grosir dan pembayaran tunai oleh pelanggan. Hal ini disarankan oleh anak Ibu Ganda.

"Saya berdasarkan inisiatif sendiri karena saya rasa perlu, kalau enggak dicatat suka lupa. Kalau dicatat kan jadi ada bukti dan tahu siapa yang beli. Awalnya ya Cuma mencatat piutang saja terus dibilang sama anak saya suruh mencatat pengeluaran bayar utang sama pembayaran yang tunai juga biar nggak keliru dalam menagih"

SEW dalam usaha keluarga milik Ibu Ganda menjadikan kesejahteraan keluarga menjadi tolok ukur utama dalam menjalankan usaha. Keterikatan antara keluarga dengan usaha yang masih sangat melekat sehingga pengelolaan keuangan lebih kepada untuk memenuhi kebutuhan keluarga. Salah satu masalah yang sering terjadi dalam usaha keluarga adalah belum adanya pemisahan antara aset atau keuangan keuarga dengan usaha yang juga terjadi di usaha keluarga Toko Ganda. Kebutuhan mendesak dari anggota keluarga bertentangan dengan nilai jangka panjang untuk usaha, meskipun demikian mereka akan tetap melakukannya walaupun dianggap tidak adil untuk kesehatan finansial usaha. Berikut pernyataan Ibu Ganda:

"Anaknya? ya tidak lah. Masa kalau anak dicatat. Tidak pernah pinjam anaknya malahan. Paling pinjam, kemudian nanti diganti dalam sehari. Kan daripada susah ambil ke bank, pinjam dulu nanti dikembalikan. tinggal keluar-keluar saja tidak dicatat, contohnya kalau mau servis mobil, tidak pernah dicatat. Ya sudah kan memang itu dikasih orang tua, jadi tinggal kasih saja. Buat apa dicatat, tidak ada yang ganti kan. Kalau dicatat malah bikin pusing."

Ibu Ganda menggunakan asas kepercayaan kepada anggota keluarga dalam penggunaan keuangan dari usaha oleh anggota keluarga. Persoalan ini menjadi alasan untuk tidak adanya pencatatan penggunaan aset usaha oleh anggota keluarga. Ibu Ganda menganggap bahwa mencatat hanya akan menambah waktu dan mempersulit diri sendiri.

"Kalau dagang itu sebenarnya tidak ada masalah karena uang kan setiap hari berputar, setiap hari kan ada, jadi memang kalau kebutuhan-kebutuhan yang terpenting (keluarga) kan harus diutamakan, ibaratnya pinjami dulu lah, pinjam uang dagangan." 
Pernyataan ini terkait dengan dimensi ketiga SEW dalam hal mengikat ikatan sosial dimana ketika salah satu anggota keluarga membutuhkan dana, maka pemilik akan memberikannya dengan suka rela meskipun dana tersebut berasal dari dana operasional. Hal ini dianggap tidak menjadi masalah penting untuk usaha keluarga selama kebutuhan utama keluarga terpenuhi maka pencatatan dan pemisahan aset tidak diperlukan.

Pencatatan pemisahan aset dalam usaha keluarga dianggap hanya akan menambah rumit pekerjaan dan juga rasa tidak enak hati kepada anggota keluarga sebagai akibat dari anggapan bahwa usaha keluarga adalah untuk keluarga sehingga tidak perlu adanya pemisahan. Pencatatan dalam penggunaan aset usaha juga dianggap sebagai anggapan negatif (rasa tidak percaya) kepada nggota keluarga sendiri.

Masalah ini berkaitan dengan dimensi keempat yaitu keterikatan emosional antar keluarga. SEW memberikan rasa sungkan terhadap keluarga sendiri di usaha keluarga ini dalam mengambil langkah atau keputusan, karena ikatan emosional yang baik kantar keluarga harus menjadi pertimbangan. Pengaruh keterikatan antara usaha dengan keluarga yang masih sangat melekat ini sejalan dengan pemikiran dalam konsep SEW dimana kesejahteraan keluarga menjadi hal yang terpenting dalam menjalankan usaha dan pengaruh besar anggota keluarga dalam pengambilan keputusan dalam pencatatan. Hal ini diungkapkan oleh Ibu Ganda:

"Setiap hari kan menghitung uang, jadi tidak tahu uang usaha yang dipakai, dipakai dulu. Tapi ya sebatas kemampuan (kebutuhan) jangan dipakai semua, paling dipakai kebutuhan hidup lah, kebutuhan sehari hari. Nanti kalau dicatat malah dikiranya tidak percaya sama keluarga sendiri"

Selain itu pencatatan secara formal atau detail juga belum dilakukan dalam usaha keluarga ini meskipun sudah pernah disarankan oleh anak dari Ibu Ganda. Selain dengan alasan tidak mau menambah waktu dan beban, menurut Ibu Ganda hal ini juga akan menyita waktunya dengan keluarga karena dalam usaha ini semua pengelolaan keuangan dilakukan sendiri oleh Ibu Ganda sebagai pemilik usaha. SEW memberikan peran penting keluarga untuk perkembangan penerapan pencatatan yang dilakukan dalam usaha. Penerapan pencatatan dipertimbangkan berdasarkan tujuan tidak terganggunya keharmonisan dalam keluarga sebelum dpengambilan keputusan. Apabila keputusan dianggap dapat mengancam keharmonisan dalam keluarga, maka hal tersebut akan dikesampingkan meskipun keputusan yang diambil mungkin akan mengganggu jalannya usaha keluarga.

"Anak saya yang pernah menyarankan untuk bikin catatan yang lebih komplit biar tau gimana kondisi keuangan Toko tapi ya ngga dijalankan soalnya ribet"

"Nanti kalau masih nambah waktu untuk bikin pencatatan detail waktunya jadi berkurang lagi. Kan kalau sudah sampe rumah sudah capek, maunya kumpul sama keluarga, masak untuk keluarga. Keuangan kan masih saya sendiri yang kelola, jadi ya kalau begitu menyita waktu."

Pencatatan transaksi secara formal ini baru akan dilakukan ketika usaha keluarga milik Ibu Ganda sudah dialihkan kepada anak Ibu Ganda.

"Nanti biar anak saya saja yang nerusin mungkin dia lebih ngerti soal pembukuan gitu."

"Nanti dari saya turun ke anak saya, Royan, atau Riki atau Pristi, atau istrinya Riki"

Pernyataan-pernyataan ini terkit dengan SEW dimensi terakhir, yaitu mengacu pada tujuan menyerahkan usaha keluarga Toko Ganda kepada generasi mendatang, karena sebuah usaha bukanlah aset yang mudah untuk dijual melainkan usaha tersebut adalah warisan dan tradisi turun temurun dari keluarga tersebut. Akibatnya, anggota keluarga memandang usaha tersebut sebagai investasi keluarga jangka panjang untuk diwariskan kepada keturunan. Terbukti pada usaha keluarga Toko Ganda ini dimana modal usaha diperoleh dari usaha dengan pemilik generasi pertama yang masih memberikan modal hingga ke generasi ketiga untuk melanjutkan usaha tersebut. Ibu Ganda juga akan memberikan usaha keluarga ini nantinya kepada salah satu dari anggota keluarga. Peralihan generasi guna melestarikan usaha yang sudah ada menjadi salah satu tujuan dalam usaha milik Ibu Ganda ini.

\section{Simpulan dan saran}

Hasil dari penelitian ini menunjukkan bahwa SEW masih tidak dapat dihindari dalam menjalankan usaha keluarga skala kecil. Anggota keluarga masih berpengaruh besar dalam pembuatan keputusan usaha, khususnya dalam pencatatan transaksi keuangan usaha di Toko Ganda. Kesejahteraan keluarga dan hubungan baik antar keluarga menjadi hal terpenting utama dalam menjalankan usaha di Toko Ganda. SEW atau keterikatan emosional antar anggota keluarga menghambat Toko Ganda dalam melakukan pencatatan secara mendetail dan terstruktur.

Keterbatasan dalam penelitian ini yaitu, obyek yang diteliti masih terlalu sedikit dengan hanya menggunakan satu objek sehingga penelitian selanjutnya diharapkan dapat menambah objek penelitian agar adanya perbandingann pencatatan-pencatatan yang di tempat atau daerah lain yang mungkin berbeda. 


\section{Daftar Rujukan}

Barney, Jay B., Richard R. Nelson, and Sidney G. Winter. 1987. "An Evolutionary Theory of Economic Change." Administrative Science Quarterly. https://doi.org/10.2307/2393143.

Barry, Bernard. 1989. "The Development of Organization Structure in the Family Firm." Family Business Review. https://doi.org/10.1111/j.1741-6248.1989.00293.x.

Berrone, Pascual, Cristina Cruz, and Luis R. Gomez-Mejia. 2012. "Socioemotional Wealth in Family Firms: Theoretical Dimensions, Assessment Approaches, and Agenda for Future Research." Family Business Review 25 (3): 258-79. https://doi.org/10.1177/0894486511435355.

BPS Provinsi DKI Jakarta. 2016. Usaha Mikro Kecil Menengah. Badan Pusat Statistik Provinsi DKI Jakarta.

Brigham, Keith H., G. T. Lumpkin, G. Tyge Payne, and Miles A. Zachary. 2014. "Researching Long-Term Orientation: A Validation Study and Recommendations for Future Research." Family Business Review 27 (1): 72-88. https://doi.org/10.1177/0894486513508980.

Burkart, Mike, Fausto Panunzi, and Andrei Shleifer. 2003. "Family Firms." Journal of Finance. https://doi.org/10.1111/1540-6261.00601.

Carrera, Nieves. 2017. "What Do We Know about Accounting in Family Firms?" Journal of Evolutionary Studies in Business-JESB 2 (2): 97-159. https://doi.org/10.1344/jesb2017.2.j032.

Cherchem, Naïma. 2017. "The Relationship between Organizational Culture and Entrepreneurial Orientation in Family Firms: Does Generational Involvement Matter?" Journal of Family Business Strategy 8 (2): 87-98. https://doi.org/10.1016/j.jfbs.2017.04.001.

Cruz, Cristina, Rachida Justo, and Julio 0. De Castro. 2012. "Does Family Employment Enhance MSEs Performance?. Integrating Socioemotional Wealth and Family Embeddedness Perspectives." Journal of Business Venturing. https://doi.org/10.1016/j.jbusvent.2010.07.002.

Eddleston, Kimberly A., and Franz W. Kellermanns. 2007. "Destructive and Productive Family Relationships: A Stewardship Theory Perspective." Journal of Business Venturing. https://doi.org/10.1016/j.jbusvent.2006.06.004.

Gallo, Miguel Ángel, Josep Tàpies, and Kristin Cappuyns. 2004. "Comparison of Family and Nonfamily Business: Financial Logic and Personal Preferences." Family Business Review. https://doi.org/10.1111/j.1741-6248.2004.00020.x.

Gomez-Mejia, Luis R., Cristina Cruz, Pascual Berrone, and Julio de Castro. 2011. "The Bind That Ties: Socioemotional Wealth Preservation in Family Firms." Academy of Management Annals 5 (1): 653707. https://doi.org/10.1080/19416520.2011.593320.

Gómez-Mejía, Luis R., Katalin Takács Haynes, Manuel Núñez-Nickel, Kathyrn J. L. Jacobson, and José Moyano-Fuentes. 2007. "Socioemotional Wealth and Business Risks in Family-Controlled Firms: Evidence from Spanish Olive Oil Mills." Administrative Science Quarterly. https://doi.org/10.2189/asqu.52.1.106.

Gomez-mejia, Luis R. 2010. "Gomez-Mejia, L.R., 2010. and Corporate Responses to Institutional Pressures : Firms Pollute Less? Pascual Berrone Martin Larraza. Administrative Science Quarterly, 55(1), Pp.82-113. Available at: Http://Search.Ebscohost.Com/Login.Aspx?Direct=true\&db=bth\&." Administrative Science Quarterly. https://doi.org/10.2307/27856089.

Hiebl, Martin R.W. 2013. "Management Accounting in the Family Business: Tipping the Balance for Survival." Journal of Business Strategy 34 (6): 19-25. https://doi.org/10.1108/JBS-07-2013-0052.

Huerta, Esperanza, Yanira Petrides, and Denise O'Shaughnessy. 2017. "Introduction of Accounting Practices in Small Family Businesses." Qualitative Research in Accounting and Management 14 (2): 
111-36. https://doi.org/10.1108/QRAM-01-2015-0008.

Irfani, Halizah, and Muhammad Dahria. 2013. "Peran Akuntansi Dalam Operasi Bisnis." Saintikom 7 (2): 383-89. https://lppm.trigunadharma.ac.id/public/fileJurnal/F15E6-OK-Jurnal7-HI-MDAKuntansi1.pdf.

Kalm, Matias, and Luis R. Gomez-Mejia. 2016. "Socioemotional Wealth Preservation in Family Firms." Revista de Administração. https://doi.org/10.1016/j.rausp.2016.08.002.

Koropp, Christian, Franz W. Kellermanns, Dietmar Grichnik, and Laura Stanley. 2014. "Financial Decision Making in Family Firms: An Adaptation of the Theory of Planned Behavior." Family Business Review. https://doi.org/10.1177/0894486514522483.

Mitchell, Falconer, and Gavin C. Reid. 2000. "Editorial. Problems, Challenges and Opportunities: The Small Business as a Setting for Management Accounting Research." Management Accounting Research. https://doi.org/10.1006/mare.2000.0152.

Niode, Idris Yanto. 2009. "Sektor UMKM Di Indonesia: Profil , Masalah, Dan Strategi Pemberdayaan." Jurnal Kajian Ekonomi Dan Bisnis OIKOS-NOMOS.

Perren, Lew, and Paul Grant. 2000. "The Evolution of Management Accounting Routines in Small Businesses: A Social Construction Perspective." Management Accounting Research. https://doi.org/10.1006/mare.2000.0141.

Poutziouris, Panikklos, Kosmas Smyrnios, Sabine Klein, and Lorraine M. Uhlaner. 2013. "Business Family as a Team: Underlying Force for Sustained Competitive Advantage." In Handbook of Research on Family Business. https://doi.org/10.4337/9781847204394.00016.

PwC, Ronghong Huang, Keng Kelvin Jui Keng Tan, Robert W. Faff, Stephen P. Ferris, David Javakhadze, Tijana Rajkovic, et al. 2016. "Survey Bisnis Keluarga 2014, Indonesia." Journal of Corporate Finance. https://doi.org/10.1016/j.jcorpfin.2015.10.009.

Salvato, Carlo, and Ken Moores. 2010. "Research on Accounting in Family Firms: Past Accomplishments and Future Challenges." Family Business Review 23 (3): 193-215. https://doi.org/10.1177/0894486510375069.

Sharma, Pramodita. 2004. "An Overview of the Field of Family Business Studies: Current Status and Directions for the Future." Family Business Review. https://doi.org/10.1111/j.17416248.2004.00001.x.

Shepherd, Dean A., Johan Wiklund, and J. Michael Haynie. 2009. "Moving Forward: Balancing the Financial and Emotional Costs of Business Failure." Journal of Business Venturing. https://doi.org/10.1016/j.jbusvent.2007.10.002.

Statistik, Subdirektorat Publikasi dan Kompilasi, ed. 2018. USAHA. Jakarta: Badan Pusat Statistik.

Stockmans, A., N. Lybaert, and Wim Voordeckers. 2010. "Socioemotional Wealth and Earnings Management in Private Family Firms." Family Business Review. https://doi.org/10.1177/0894486510374457.

Sulistyo. 2010. "Pengembangan Usaha Kecil Dan Menengah Dengan Basis Ekonomi Kerakyatan Di Kabupaten Malang." Jurnal Ekonomi MODERNISASI Fakultas Ekonomi - Universitas Kanjuruhan Malang Http://Ejournal.Ukanjuruhan.Ac.Id. https://doi.org/97-30449.

Tsamenyi, Mathew, Irvan Noormansyah, and Shahzad Uddin. 2008. "Management Controls in FamilyOwned Businesses (FOBs): A Case Study of an Indonesian Family-Owned University." Accounting Forum. https://doi.org/10.1016/j.accfor.2006.10.001.

Wahjono, Sentot Imam Universitas Muhammadiyah Surabaya. 2009. "Suksesi Dalam Perusahaan 
Keluarga." Balance.

Williamson, Oliver E. 1985. "The Economic Institutions of Capitalism - Transaction Cost Economics." In The Political Economy Reader Markets as Institutions.

Zellweger, Thomas M., Franz W. Kellermanns, James J. Chrisman, and Jess H. Chua. 2011. "Family Control and Family Firm Valuation by Family CEOs: The Importance of Intentions for Transgenerational Control." Organization Science. https://doi.org/10.1287/orsc.1110.0665.

Zellweger, Thomas M., Robert S. Nason, Mattias Nordqvist, and Candida G. Brush. 2013. "Why Do Family Firms Strive for Nonfinancial Goals? An Organizational Identity Perspective." Entrepreneurship: Theory and Practice. https://doi.org/10.1111/j.1540-6520.2011.00466.x. 